\section{Attitudes of Consumers and Recently Bereaved Toward Sympathy Flowers}

\author{
Candice A. Shoemaker ${ }^{1}$ and P. Diane Relf \\ Department of Horticulture, Virginia Polytechnic Institute and State University, \\ Blacksburg, VA 24061
}

Additional index words. survey questionnaire, funeral rituals, human issues in horticulture

\begin{abstract}
Surveys of consumers and the recently bereaved were conducted to determine who sends flowers as a sympathy gift and when and why sympathy flowers are sent. Of consumers, $85 \%$ sent flowers as a sympathy gift at least once; similarly, $84 \%$ of the recently bereaved had sent sympathy flowers. Most sympathy flowers are sent to close friends $(63 \%)$ and close family members $(62 \%)$, and sympathy flowers are most often received from close friends $(56 \%)$ and close family members $(43 \%)$. Ninety-three percent send flowers as a sympathy gift immediately after notification of a death. According to our survey, sympathy flowers serve two roles in the bereavement process-an emotional and a functional role. Except contact of family and friends, participants indicated that receiving sympathy flowers to help deal with grief was equally or more valuable than all rituals associated with funerals.
\end{abstract}

An important sector of the florists' business is sympathy flowers and funeral tributes. In our extensive review of the literature, including horticulture, marketing, psychology, sociology, and grief journals, we failed to uncover any research conducted to determine the role that flowers have in the funeral ritual. Understanding the role of sympathy flowers in funeral rituals and the buying behavior of consumers and recently bereaved could help florists better serve their customers and develop effective marketing strategies. An industry study conducted for Interflora (Indepth Research, 1984), consisting of interviews with individuals, was limited in scope. Therefore, the objectives of our research were to determine who sends flowers as a sympathy gift, when they are sent, and why they are sent.

\section{Materials and Methods}

Two written questionnaires were developed to survey individuals in an established consumer panel and from a database of recently bereaved. Questions were based on information gained from personal interviews with psychologists and sociologists, focus group interviews with individuals who experienced the loss of a loved one in the preceding 5 years, and surveys of funeral directors and grief therapists.

Consumer survey. Eleven questions concerning buying behaviors, attitudes toward receiving sympathy flowers, and the use of

Received for publication 20 Dec. 1993. Accepted for publication 15 Mar. 1994. This study was funded with a grant from the Society of American Florists and the American Floral Endowment. The cost of publishing this paper was defrayed in part by the payment of page charges. Under postal regulations, this paper therefore must be hereby marked advertisement solely to indicate this fact.

${ }^{1}$ Currently, Assistant Professor, Dept. of Animal and Horticultural Sciences, Berry College, Mt. Berry, GA 30149. flowers at funerals were included in the Feb. 1990 Better Homes and Gardens (BH\&G) consumer panel questionnaire. The consumer panel was established in 1976 to expand the flow of up-to-date information between the business sector and consumers. This questionnaire was mailed to 500 nationally distributed members of a 1000 -member $\mathrm{BH} \& \mathrm{G}$ consumer panel. The consumer panel was developed from a randomly selected sample of 5000 $B H \& G$ subscribers to demographically represent all BH\&G subscribers. A demographic comparison of the $\mathrm{BH} \& \mathrm{G}$ consumer panel and U.S. family households (U.S. Bureau of the Census, 1990; U.S. Dept. of Commerce, 1990; U.S. Dept. of Labor, 1989) indicated that the median age, marital status, geographic distribution, and percentage of female heads of household were similar, although more of the $\mathrm{BH} \& \mathrm{G}$ consumer panel were college graduates and homeowners with higher median incomes. The questionnaire contained 124 items concerning 11 product categories. The questionnaire was completed by 398 participants (80\% response).

Survey of bereaved. A random sample of 4600 names and addresses was selected from a purchased database of 120,000 recently widowed men and women (Lifestyle Changes Information Management, 1989). The database consisted of individuals who had responded to a national lifestyle change questionnaire in 1989. A questionnaire with a cover letter was mailed on 11 June 1990, and a reminder card was sent 1 week later. There were 99 nondeliverable addresses in the original random sample. The final sample was 1852 (41\% response), providing a sampling error of $3 \%$ at a $95 \%$ confidence level.

The questionnaire for the recently bereaved consisted of four sections. Section 1 focused on the effectiveness of specific rituals associated with death and funerals in working through grief. Section 2 addressed the meaning or value of funeral flowers, using statements, such as "flowers are a critical component of the funeral ritual," "sending flowers is a way I show someone I care," and "flowers at the funeral make me feel good." The respondents were asked to what extent they agreed or disagreed with each statement. Section 3 contained multiple choice and short answer questions regarding opinions and thoughts about sympathy flowers, such as "why do you think most people send flowers as a sympathy gift?" and "why do you send flowers or plants as a sympathy gift?" Section 4 contained demographic information.

\section{Results and Discussion}

Consumer survey. The results of our consumer survey indicate that giving flowers continues to be an important tradition. Of those surveyed, the majority have received and sent flowers as a sympathy gift. Eighty-five percent had sent flowers as an expression of sympathy. When someone close to them had died, $67 \%$ had received flowers as a sympathy gift, 30\% never had received flowers, and 3\% did not respond.

The consumer respondents were asked from whom they had received flowers and to whom they had sent flowers as a sympathy gift. Most sympathy flowers were sent and received by close family members and close friends (Tables 1 and 2). When asked why they sent flowers as a sympathy gift, the primary reason was to comfort survivors.

The majority (93\%) sent flowers immediately after notification of the death, $5 \%$ sent them after the funeral service, and $1 \%$ sent them weeks or months after the death or to

Table 1. Responses from a mailed survey to nationally distributed consumers $(n=398)$ to the question "who have you received flowers from and sent flowers to as a sympathy gift?"

\begin{tabular}{lcc}
\hline & \multicolumn{2}{c}{ Response (\%) } \\
\cline { 2 - 3 } Category & Received from & Sent to \\
\hline Close friends & 56 & 63 \\
Close family members & 43 & 62 \\
Business associates & & \\
$\quad$ or acquaintances & 42 & 30 \\
Other relatives & 34 & 44 \\
Neighbor & 30 & 34 \\
Church members & 21 & 16 \\
Casual friends & 16 & 13 \\
Club members & 12 & 10 \\
No answer & 3 & 2 \\
\hline
\end{tabular}

Table 2. Responses from a survey of bereaved $(\mathrm{n}=$ $1852)$ and a consumer survey $(n=398)$ for the question "why have you sent flowers or plants as a sympathy gift?"

\begin{tabular}{|c|c|c|}
\hline \multirow[b]{2}{*}{ Category } & \multicolumn{2}{|c|}{ Response (\%) } \\
\hline & $\overline{\text { Bereaved }^{z}}$ & Consumers $^{\mathrm{y}}$ \\
\hline $\begin{array}{l}\text { To comfort } \\
\text { the survivors }\end{array}$ & 51 & 84 \\
\hline $\begin{array}{l}\text { Respect for } \\
\text { the deceased }\end{array}$ & 29 & 51 \\
\hline $\begin{array}{l}\text { To acknowledge } \\
\text { the death }\end{array}$ & 7 & 35 \\
\hline $\begin{array}{l}\text { It is socially expected } \\
\text { To comfort me }\end{array}$ & 7 & 14 \\
\hline
\end{tabular}

${ }^{\mathrm{z}}$ Respondents selected the single best answer.

yespondents marked all answers that applied. 
recognize the anniversary of the death. This question was based on responses from individuals in a prior focus group, expressing the desire that "some of the flowers had come throughout the year." This response implies that some individuals who have experienced the loss of a loved one want to be remembered in the months following the death, but a low percentage of people actually sending flowers at this time may indicate a potential area for market development in the floral industry.

When consumers were asked which of three statements best reflected their feelings about flowers at funerals, 53\% thought flowers were a necessary part of funerals, $37 \%$ thought there were too many flowers at funerals, and $8 \%$ thought there was no need for

Survey of bereaved. The typical respondent in this sample was a retired protestant woman between the ages of 50 and 79 with at least a high school degree. As expected, there were more women than men in the bereaved sample because there are more widowed women in the general population. Annual income was evenly distributed from $\$ 5,000$ to $\$ 50,000$. In most cases, the relationship of the respondent to the deceased was spouse, although a few were siblings, parents, or children.

The first section of the questionnaire focused on specific rituals associated with death and funerals and their efficacy as an aid in working through grief. Table 3 lists the most important seven of 28 items from section 1 of the questionnaire, with the percentage of respondents who indicated that the stated item helped them a great deal with their grief. The range of the true response, based on a sampling error of $3 \%$ at the $95 \%$ confidence level, indicates that receiving sympathy flowers and receiving sympathy cards were considered to be equally valuable, ranking second after conflowers at funerals.

tact with family and friends. Both were more helpful than receiving notification of memorial donations, eulogy, food, or visits-all of which were of equal value. The study indicated that receiving tangible items, such as sympathy flowers, sympathy cards, notification of memorial donations, and food helped women with their grief more than it helped men (Table 3).

Sections 2 and 3 of the survey focused specifically on flowers in funeral rituals. The data indicated that flowers play a functional role in the funeral. Fifty-three percent strongly agreed or agreed that flowers and plants provided a diversion during the visit or viewing, and $77 \%$ strongly agreed or agreed that flowers brightened up the somber environment of the funeral home. There was also a desire to have the option of giving living plants for a funeral. Fifty-three percent strongly agreed or agreed with the statement "I prefer giving living plants, bulbs, or seeds as a memorial for the deceased rather than a cut flower arrangement." However, 53\% strongly disagreed or disagreed with the statement "artificial flowers are a nice memorial to keep." This information identifies another market for exploration by the florist industry.

Declining sales of sympathy flowers (Foster, 1988) has led to advertising. The Florist Information Committee (1989) of the Society of American Florists has developed sample advertisement slogans for florists such as "Sympathy flowers-providing comfort to loved ones ... and a tribute to the one they loved" and "Sympathy flowers-an expression of love." Section 2 contained three statements to test the validity of these slogans and to explore the emotional meaning people associate with sending or receiving flowers. Of the respondents, $\approx 89 \%$ strongly agreed or agreed with the statement "sympathy flowers and plants symbolize the love and care of people."

Table 3. Percentage of respondents from a nationwide survey of bereaved $(n=1852)$ who responded at level four or above on a scale of 1 (did not help at all) to 6 (helped a great deal) and the mean response of male and female respondents to how much each of the stated items helped them with their grief.

\begin{tabular}{lcccr}
\hline & & \multicolumn{2}{c}{ Mean response } \\
\cline { 3 - 5 } Category & Response $(\%)^{\mathrm{z}}$ & Males & Females & $\chi^{2}$ \\
\hline Family and friends & 93 & 5.5 & 5.7 & $7.4^{\mathrm{ss}}$ \\
Receiving sympathy cards & 83 & 4.6 & 5.2 & $30.9^{* * *}$ \\
Receiving sympathy flowers & 78 & 4.4 & 5.0 & $30.0^{* * * *}$ \\
Receiving memorial donations & 70 & 4.3 & 4.9 & $29.1^{* * *}$ \\
Eulogy & 68 & 4.6 & 4.8 & $5.3^{\mathrm{Ns}}$ \\
Receiving food & 68 & 4.3 & 4.8 & $19.9^{* * *}$ \\
Visitation $^{\mathrm{y}}$ & 65 & 4.4 & 4.7 & $5.3^{\mathrm{Ns}}$ \\
\hline
\end{tabular}

${ }^{2}$ Sampling error is $2.5 \%$ at the $95 \%$ confidence level.

${ }^{y}$ Visiting or viewing the deceased for 1 to 2 days before the funeral and burial.

ss,****Nonsignificant or significant at $P \leq 0.001$, respectively.
Eighty-seven percent strongly agreed or agreed with the statement "sympathy flowers and plants are a thoughtful expression of concern for the survivors," and $84 \%$ strongly agreed or agreed with the statement "sending flowers is a way I show someone I care." Of those who had sent flowers as a sympathy gift, 51\% responded that they did so "to comfort the survivors" (Table 2). Our results indicate that the bereaved perceive sympathy flowers as a symbol of the love, care, and concern that family and friends have for them. Similar results were reported by Indepth Research for Interflora (1984) from interviews of individuals who had been involved with a funeral during the previous 12 months.

This research shows that the consumer and the recently bereaved consider sympathy flowers an important part of the funeral ritual. In both groups, the majority of respondents sent or received flowers as a sympathy gift. Close friends and close family members most often send and receive sympathy flowers and plants. Sympathy flowers provide a tangible way for people to show concern and care for the bereaved, with the majority sending flowers immediately after notification of the death. Our data provide the florist industry with tools to serve their customers better and to expand their market potential.

\section{Literature Cited}

de Vaus, D.A. 1986. Surveys in social research. Geo Allen \& Unwin, Boston.

Florist Information Committee. 1989. Sympathy flower advertising. Soc. Amer. Florists, Alexandria, Va.

Foster, K. 1988. Beating the odds. SAF Business News for the Floral Industry 5(8):20-26, 37, 43.

Indepth Research. 1984. Report on a small-scale qualitative research study to explore, examine, and assess consumer attitudes, feelings, needs, and motivations towards sympathy flowers. Indepth Research, London.

Life Style Changes Information Management. 1989. Research grant information, segment: Widows and widowers, national. Life Style Changes Information Management, Atlanta, Ga.

U.S. Bureau of the Census. 1990. Current population reports, series P-20, no. 458; series P-60, no. 174. U.S. Bureau of the Census, Washington, D.C.

U.S. Dept. of Commerce, Bureau of the Census. 1990. Census of population and housing. U.S. Dept. of Commerce, Bureau of the Census, Washington, D.C.

U.S. Dept. of Labor, Bureau of Labor Statistics. 1989. Handbook of labor statistics. Bul. 2340. U.S. Dept. of Labor, Bureau of Labor Statistics, Washington, D.C. 